\title{
Investigation of the Possible Role of Chlamydophila abortus in Reproductive Failures in Brazilian Herds of Domestic Ruminants
}

\author{
Francielle Gibson da Silva-Zacarias ${ }^{1}$, Amauri Alcindo Alfieri ${ }^{2}$, Kledir Anderson \\ Hofstaetter Spohr ${ }^{1}$, Bruna Azevedo de Carvalho Lima ${ }^{1}$, Rosângela Claret de Oliveira ${ }^{3}$, \\ Carlo Turilli ${ }^{4}$, Michele Lunardi ${ }^{2}$, Rodrigo Alejandro Arellano Otonel ${ }^{2}$ and Julio Cesar de \\ Freitas ${ }^{*}$ \\ ${ }^{1}$ Laboratório de Leptospirose; Departamento de Medicina Veterinária Preventiva; Universidade Estadual de \\ Londrina; Londrina - PR - Brasil. ${ }^{2}$ Laboratório de Virologia Animal; Departamento de Medicina Veterinária \\ Preventiva; Universidade Estadual de Londrina; Londrina - PR - Brasil. Departamento de Medicina Veterinária \\ Preventiva; Universidade de São Paulo; São Paulo - SP - Brasil. ${ }^{4}$ Istituto Zooprofilattico Sperimentale delle \\ Venezie; Padova - Italy
}

\begin{abstract}
Chlamydophila abortus (C. abortus) infection is related to reproductive failure in domestic ruminants. Although it has not been well characterized worldwide, this pathogen has already been identified in some European countries and in the USA. In Brazil, preliminary studies have shown serological evidence of C. abortus infection in herds with low antibody prevalence. Until now, the identification of $C$. abortus in biological samples from females presenting reproductive failures has not been described in Brazilian herds of domestic ruminants. The aim of this study was to evaluate the presence of the $C$. abortus in a collection of abortions from cattle $(n=85)$, sheep $(n=12)$, and goats $(n=8)$, in samples of vaginal mucus from cows $(n=13)$, sheep $(n=90)$, and goats $(n=20)$, and in semen from sheep $(n=10)$ and goats $(n=5)$. The specimens $(n=243)$ were evaluated using a PCR assay developed to amplify the 16S23S rRNA intergenic space of C. abortus. A PCR assay with an internal control, which amplifies a fragment from the ND5 gene of bovine mitochondrial DNA, was used in order to evaluate the efficiency of the DNA extraction and of the PCR reaction. All biological samples $(n=243)$ included in this study were negative for $C$. abortus in the PCR assay. The internal control enabled the amplification of a product from the bovine mitochondrial ND5 gene in all cattle abortion samples $(n=85)$. Given the serological evidence indicating the presence of $C$. abortus infection in Brazilian herds of domestic ruminants, and considering the wide sampling evaluated, the failure to identify $C$. abortus in this survey suggests that the frequency of clinical signs in infected animals may be low or even absent.
\end{abstract}

Key words: cattle, small ruminants, Chlamydophila abortus, abortion, vaginal mucus, semen

\section{INTRODUCTION}

Chlamydophila abortus (C. abortus), the etiological agent of caprine and ovine enzootic abortion (OEA) and of epizootic bovine abortion (EBA), is considered to be endemic in ruminants from several regions in the world (Everett, 2000; Greco et al., 2005). OEA might result in abortion

\footnotetext{
*Author for correspondence: freitasj@uel.br
} 
rates greater than $30 \%$ shortly after its entrance into a herd; however, this rate drops to $5-10 \%$ when the endemic form of the infection is established (Masala et al., 2005). In most European countries, OEA is considered the main cause of abortion, accounting for 39\% and 50\% of sheep abortions in Switzerland and the United Kingdom, respectively, and for $23 \%$ of goat abortions in Switzerland (Wood, 1992; Borel et al., 2004).

Besides causing abortion, C. abortus also reduces fertility in infected cows and bulls due to endometritis and epididymitis/seminal vesiculitis, respectively (Livingstone and Longbottom, 2006). Depending on the sampling method used and the evaluated region, different polymerase chain reaction (PCR) assays have detected C. abortus infection in 0.8 to $60 \%$ of animals tested (Kaltenboeck et al., 2005; Reitt et al., 2007). Precise data demonstrating the negative impact of EBA and other chlamydophyla infections on the reproductive efficiency in cattle are not available (Reinhold et al., 2007).

Several methods have been employed for diagnosis of $C$. abortus. While conventional techniques, such as culture in embryonated chicken eggs or in continuous cell lines, have a low sensitivity, molecular methods, such as PCR assays, are considered the most suitable tools for detecting $C$. abortus in abortion and semen samples (Everett, 2000; Amim, 2003; Reitt et al., 2007). The aim of this study was to investigate the presence of $C$. abortus in biological samples from bovine, ovine, and caprine abortions, in vaginal mucus from bovines, ovines and caprines, and semen samples from ovines and caprines using a PCR assay.

\section{MATERIALS AND METHODS}

\section{Clinical specimens}

We evaluated clinical specimens collected from 105 abortions in cattle $(n=85)$, sheep $(n=12)$, and goats $(n=8) ; 123$ vaginal discharge samples from cattle $(n=13)$, sheep $(n=90)$, and goats $(n=20)$; and 15 semen samples from sheep $(n=10)$ and goats $(n=5)$. All animals were from Brazilian cattle or domestic ruminant herds that had experienced reproductive failures. While cattle presenting abortion were from three geographical regions of Brazil (south, southeast, and center-west), the small ruminants evaluated were all from the Paraná state.

\section{DNA extraction}

Fragments of the liver, spleen, and lungs from aborted fetuses were ground in phosphate-buffered saline solution (PBS, pH 7.2), and the suspensions $(10 \% \mathrm{w} / \mathrm{v})$ were centrifuged at $1000 \mathrm{x} g$ for $5 \mathrm{~min}$ at $4^{\circ} \mathrm{C}$. Vaginal mucus samples and semen samples were also diluted in PBS (20\% v/v). Aliquots $(400 \mu \mathrm{L})$ from the supernatants were treated with lysis buffer $(10 \mathrm{mM}$ Tris, $1 \mathrm{mM}$ EDTA, $0.5 \%$ Nonidet P40, 1\% SDS, and 0.2 $\mathrm{mg} / \mathrm{mL}$ proteinase K). For nucleic acid extraction, the silica/guanidine isothiocyanate method was used (Boom et al., 1990). The positive controls consisted of the vitelline sac of embryonated chicken eggs inoculated with the C. abortus S26/3 strain. Sterile ultrapure water was included as negative control in all DNA extraction procedures.

\section{PCR assay}

In order to identify $C$. abortus in the evaluated specimens, a PCR assay that amplifies an 856-bp product from the intergenic region between the $16 \mathrm{~S}$ and $23 \mathrm{~S}$ rRNA genes was carried out according to Silva-Zacarias et al. (2009a). The reactions were performed using $5 \mu \mathrm{L}$ of extracted DNA and $45 \mu \mathrm{L}$ of PCR-mix consisting of 20 pmol of each primer [Ldn 2 (5'CCCAAGGTGAGGCTGATGAC-3', positive sense, nt 1470-1489 of the 16S rRNA gene) and Ldn 4 (5'-GTTTCAGGTTCTATTTCACTCCC3', negative sense, nt 2303-2325 of 23S rRNA gene)], $0.2 \mathrm{mM}$ of each dNTP, 2.5 units of Platinum Taq DNA polymerase (Invitrogen Life Technologies, BR), $1.5 \times$ PCR buffer $(30 \mathrm{mM}$ Tris$\mathrm{HCl}, \mathrm{pH} 8.4$, and $75 \mathrm{mM} \mathrm{KCl}$ ), $2 \mathrm{mM} \mathrm{MgCl}$, and ultrapure sterile water to a final volume of $50 \mu \mathrm{L}$. Amplification was performed in a thermocycler (PTC 200, MJ Research Co., USA) with the following cycling profile: an initial step of $4 \mathrm{~min}$ at $94{ }^{\circ} \mathrm{C}$, followed by 40 cycles of $1 \mathrm{~min} / 94{ }^{\circ} \mathrm{C}$, $1 \mathrm{~min} / 59{ }^{\circ} \mathrm{C}, 1 \mathrm{~min} / 72{ }^{\circ} \mathrm{C}$, and a final extension step of $7 \mathrm{~min} / 72{ }^{\circ} \mathrm{C}$.

Additionally, the efficiencies of the nucleic acid extraction and DNA amplification procedures for the bovine abortion samples were evaluated by a PCR assay employing an internal control. These reactions were carried out with primers BOV1 (5'ATACGCCTTCATTACCAG-3') and BOV2 (5'TTGAATGGAGTAGTGCTG-3'), which amplify 
a 626-bp amplicon from the ND5 gene of bovine mitochondrial DNA (Wosiacki et al., 2005).

Aliquots of $10 \mu \mathrm{L}$ from each PCR reaction were analyzed by electrophoresis on a $2 \%$ agarose gel run at a constant voltage $(90 \mathrm{~V})$ for approximately $45 \mathrm{~min}$. The gel was stained with ethidium bromide $0.5(\mu \mathrm{g} / \mathrm{mL})$ in TBE buffer, $\mathrm{pH} 8.4(89$ $\mathrm{mM}$ Tris, $89 \mathrm{mM}$ boric acid, $2 \mathrm{mM}$ EDTA) and visualized under UV light.

\section{RESULTS AND DISCUSSION}

All 243 samples included in this study were considered to be negative for $C$. abortus. Additionally, background PCR amplification could not be visualized on the agarose gel. The PCR amplification of a 626-bp amplicon of the ND5 gene of bovine mitochondrial DNA was visible in all 85 samples from bovine abortions (Fig. 1). The use of an internal control and the presence of negative and positive controls in all steps of the DNA extraction and the PCR assay minimized the possibility of false negative results in the evaluated samples.

The failure to detect $C$. abortus in this survey is probably not due to the low sensitivity of the detection method used. In a previous study, this PCR assay was shown to have a detection threshold 100-fold lower than the PCR system described for the Omp2 (outer major protein) gene of the Chlamydiaceae family. In addition, positive reactions could be observed when employing dilutions of suspensions of artificially contaminated fetal bovine organs down to 1.05 IFU (inclusion-forming units) of $C$. abortus, confirming the sensitivity of the technique (SilvaZacarias et al., 2009a).

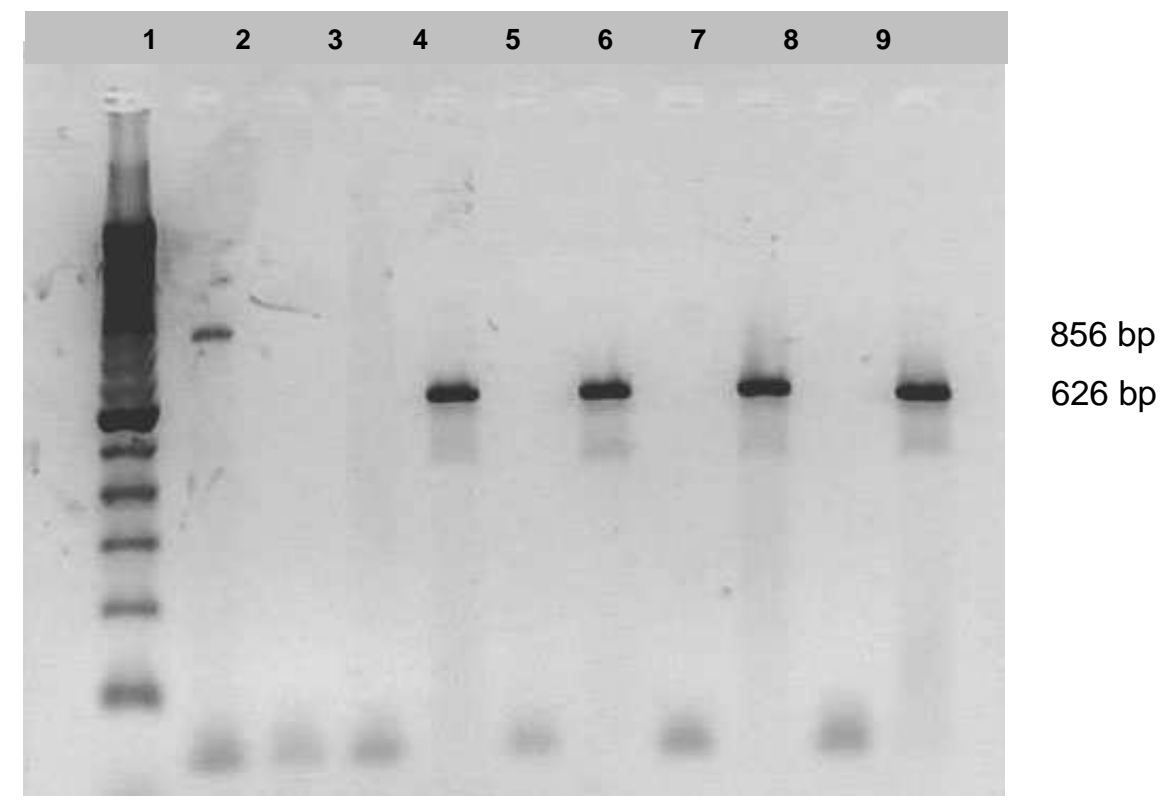

Figure 1 - Agarose gel electrophoresis of rRNA PCR products of Chlamydophila abortus (856 bp) and BOV1/2 PCR products of the ND5 gene of bovine mitochondrial DNA (internal control, $626 \mathrm{bp}$ ) in samples from bovine abortions. Lane 1: $100 \mathrm{bp}$ molecular size marker (Invitrogen ${ }^{\mathrm{TM}}$, USA); Lane 2: positive control (embryonated chicken egg inoculated with $C$. abortus); Lane 3: embryonated chicken egg inoculated with $C$. abortus and negative for the internal control reaction; Lanes 4, 6, 8, and 10: samples from bovine abortions negative for $C$. abortus; Lanes 5, 7, 9, and 11: samples from bovine abortions positive for the internal control reaction. 
Infectious reproductive diseases of ruminants are caused by diverse classes of microorganisms (bacteria, viruses, protozoa) and may occur as single or mixed infections. Both the use of vaccines, available for some microorganisms, and the endemic character of some infections make serology inefficient as a diagnostic tool.

Therefore, the definitive identification of most microorganisms may only be obtained through etiological diagnosis.

Serological investigations for $C$. abortus infections have demonstrated a low prevalence in Brazilian ruminant herds. A comprehensive study involving the analysis of 3,102 serum samples from cattle herds $(n=373)$ in diverse geographical regions of the Paraná state showed an estimated prevalence of $1.42 \%$ and $8.82 \%$ for positive animals and positive herds, respectively (Silva-Zacarias et al., 2009b). In the São Paulo state, in a limited investigation, a prevalence of $5.3 \%$ and $51.9 \%$ was found for positive animals and positive herds, respectively (Igayara-Souza et al., 2004). The disagreement between the prevalence rates indicated in these studies may be due to the different methodologies adopted for definition of the sampling. In ovine herds from the Paraná state, serological evidence has also indicated the presence of C. abortus (Lima, 2007). Although the serological evidence for $C$. abortus infections in Brazilian domestic ruminant herds does not define its geographical distribution, it confirms the presence of the agent in Brazilian herds.

C. abortus infection is not always followed by clinical signs in ruminants. In some situations, the infection might be present in a latent form, and a seropositive animal might not present any clinical signs (Reinhold et al., 2007).

In Brazil, reproductive failures represent the main sanitary problem in cattle herds (Takiuchi et al., 2005; Cortez et al., 2006a, 2006b; Junqueira and Alfieri, 2006; Rufino et al., 2006; Pilz el al., 2007; Dias et al., 2008). Despite being endemic in Brazilian beef and dairy cattle, Leptospirosis, Infectious Bovine Rhinotracheitis (IBR), and the Bovine Viral Diarrhea (BVD) can be controlled through vaccination programs (Junqueira et al., 2006). Despite using sensitive and specific laboratorial tools, the etiological diagnosis remains undetermined in most cases of bovine abortion, both in vaccinated and in non-vaccinated herds. It is clear that in these situations the inclusion of other potential pathogens, such as C. abortus, would be of great value in the identification of the etiology. Although the analyses performed in this study did not show the presence of $C$. abortus in the evaluated specimens from cattle, sheep, and goats, the sanitary and economic importance attributed to this disease in the Northern hemisphere, its zoonotic potential, and the serological evidence for $C$. abortus infection in Brazilian herds justify the pursuit of further studies on the epidemiology of this infection in domestic ruminants in Brazil.

\section{ACKNOWLEDGEMENTS}

The financial resources for the conduction of this study were supported by the project BioAgroPar financed by FINEP, SETI/PR, and Fundação Araucária/PR; and by CNPq/Brazil.

Part of the research activities of this study was carried out in the Agricultural Research Support Laboratory (Laboratório de Apoio à Pesquisa Agropecuária - LAPA) / PROPPG / UEL.

Alfieri A.A. is recipient of CNPq fellowship.

\section{RESUMO}

A infecção pela Chlamydophila abortus ( $C$. abortus) em ruminantes domésticos está relacionada com distúrbios reprodutivos. Apesar de ainda pouco estudada em todo o mundo, a infecção já foi identificada em alguns países europeus e também nos EUA. No Brasil, estudos preliminares demonstraram evidências sorológicas da infecção em alguns rebanhos com baixa prevalência de anticorpos. Até o momento ainda não foi possível a identificação de $C$. abortus a partir de material biológico proveniente de fêmeas com problemas reprodutivos em rebanhos brasileiros. O objetivo deste trabalho foi avaliar a presença da $C$. abortus em uma coleção de abortos bovinos $(n=85)$, ovinos $(n=12)$ e caprinos $(n=8)$, em amostras de muco vaginal bovino $(n=13)$, ovino $(n=90)$ e caprino $(n=20)$, e em sêmen ovino $(n=10)$ e caprino $(n=5)$. As amostras biológicas $(n=243)$ foram avaliadas por meio de técnica de PCR desenvolvida para a amplificação do espaço intergênico 16S-23S RNAr da C. abortus. Um controle interno da reação, que amplifica um fragmento do gene ND5 do DNA mitocondrial de bovino, foi utilizado para a avaliação da eficiência da extração e da amplificação do DNA nas amostras provenientes de abortamento bovino. 
Todas as amostras biológicas $(n=243)$ incluídas nesse estudo resultaram negativas para a $C$. abortus na PCR. O controle interno da reação possibilitou a amplificação de um produto do gene ND5 mitocondrial bovino em todas as amostras de aborto bovino $(n=85)$. Apesar de evidências sorológicas indicarem a presença da infecção por $C$. abortus em rebanhos de ruminantes no Brasil, e considerando o número de amostras biológicas avaliadas, a não identificação de $C$. abortus nesse estudo sugere que a frequência de sinais clínicos nos animais infectados pode ser baixa ou mesmo ausente.

\section{REFERENCES}

Amim, A. S. (2003), Application of touchdown enzyme time release (TETR)-PCR for diagnosis of Chlamydophila abortus infection. Res Vet Sci, 74, 213-217

Boom, R., Sol, C. J., Salimans, M. M., Jansen, C. L., Wertheim-van Dillen, P. M., van der Noordaa, J. (1990), Rapid and simple method for purification of nucleic acids. J Clin Microbiol, 28, 495-503

Borel, N., Doherr, M. G., Vretou, E., Psarrou, E., Thoma, R., Pospischil, A. (2004), Seroprevalences for ovine enzootic abortion in Switzerland. Prev Vet Med, 65, 205-216

Cortez, A., Castro, A. M. G., Heinemann, M. B., Soares, R. M., Leite, R. C., Scarcelli, E., Genovez, M. E., Alfieri, A. A., Richtzenhain, L. J. (2006a), Detecção de ácidos nucléicos de Brucella spp., Leptospira spp., herpesvírus bovino e vírus da diarréia viral bovina, em fetos bovinos abortados e em animais mortos no perinatal. Arq Bras Med Vet Zootec, 58, 1226-1228

Cortez, A., Heinemann, M. B., Castro, A. M. M. G., Soares, R. M., Pinto, A. M. V., Alfieri, A. A., Flores, E. F., Leite, R. C., Richtzenhain, L. J. (2006b), Genetic characterization of Brazilian bovine viral diarrhea virus isolates by partial nucleotide sequencing of the 5'-UTR region. Pesq Vet Bras, 26, 211-216

Dias, J. A., Alfieri, A., Médici, K. C., Freitas, J. C., Neto, J. S. F., Müller, E. E. (2008), Fatores de risco associados à infecção pelo herpesvírus bovino $1 \mathrm{em}$ rebanhos bovinos da região Oeste do Estado do Paraná. Pesq Vet Bras, 28, 161-168

Everett, K. D. E. (2000), Chlamydial and Chlamydiales: more than meet the eye. Vet Microbiol, 75, 109-126

Greco, G., Totaro, M., Madio, A., Tarsitano, E., Fasanella, A., Lucifora, G., Buonavoglia, D. (2005), Detection of Chlamydophila abortus in sheep and goat flocks in southern Italy by PCR using four different primer sets. Vet Res Commun, 29, 107-115
Igayara-Souza, C. A., Genovez, M. E., Ferreira, F., Paulin, L. M., Scarcelli, E., Cardoso, M. V., Turilli, C. (2004), Ocorrência de anticorpos antichlamydophila em bovinos e sua relação com distúrbios reprodutivos. Rev Bras Rep Anim, 28, 2833

Junqueira, J. R. C., Alfieri, A. A. (2006), Falhas da reprodução na pecuária bovina de corte com ênfase para causas infecciosas. Semina Ci Agr, 27, 289-298

Junqueira, J. R. C., Freitas, J. C., Alfieri, A. F., Alfieri, A. A. (2006), Avaliação do desempenho reprodutivo de um rebanho bovino de corte naturalmente infectado com o BoHV-1, BVDV e Leptospira hardjo. Semina Ci Agr, 27, 471-480

Kaltenboeck, B., Hehnen, H. R., Vaglenov, A. (2005), Bovine Chlamydophila spp. infection: do we underestimate the impact on fertility? Vet Res Commun, 29, 1-15

Lima, B. A. C. (2007), Prevalência de anticorpos contra Chlamydophila spp em ovinos de propriedades localizadas na região de Londrina, Paraná. MS Dissertation, Universidade Estadual de Londrina, Londrina, Brazil

Livingstone, M., Longbottom, D. (2006), What is the prevalence and economic impact of chlamydial infections in cattle? The need to validate and harmonise existing methods of detection. Vet $J, \mathbf{1 7 2}$, 3-5

Masala, G., Porcu, R., Sanna, G., Tanda, A., Tola, S. (2005), Role of Chlamydophila abortus in ovine and caprine abortion in Sardinia, Italia. Vet Res Commun, 29, 117-123

Pilz, D., Alfieri, A. F., Lunardi, M., Alfieri, A. A. (2007), RT-PCR em pools de soros sangüíneos para o diagnóstico da infecção aguda e de animais persistentemente infectados pelo vírus da diarréia viral bovina. Arq Bras Med Vet Zootec, 59, 1-7

Reinhold, P., Jaeger, J., Liebler-Tenorio, E., Berndt, A., Bachmann, R., Schubert, E., Melzer, F., Elschner, M., Sachse, K. (2007), Impact of latent infections with Chlamydophila species in young cattle. Vet $J, \mathbf{1 7 5}$, 202-211

Reitt, K., Hilbe, M., Voegtlin, A., Corboz, L., Haessig, M., Pospischil, A. (2007), Aetiology of bovine abortion in Switzerland from 1986 to 1995 - a retrospective study with emphasis on detection of Neospora caninum and Toxoplasma gondii by PCR. $J$ Vet Med A Physiol Pathol Clin Med, 54, 15-22

Rufino, F. A., Seneda, M. M., Alfieri, A. A. (2006), Impacto do herpesvírus bovino 1 e do vírus da diarréia viral bovina na transferência de embriões. Arch Vet Sci, 11, 78-84

Silva-Zacarias, F. G., Alfieri, A. A., Spohr, K. A. H., Lima, B. A. C., Negrão, F. J., Lunardi, M., Freitas, J. C. (2009a), Validation of a PCR assay for Chlamydophila abortus rRNA gene detection in a murine model. Braz Arch Biol Technol, 52, 99-106 
Silva-Zacarias, F. G., Spohr, K. A. H., Lima, B. A. C., Dias, J. A., Müller, E. E., Neto, J. S. F., Turilli, C., Freitas, J. C. (2009b), Prevalência de anticorpos antiChlamydophila spp. em propriedades rurais com histórico de aborto bovino no estado do Paraná. Pesq Vet Bras, 29, 215-219

Takiuchi, E., Medici, K., Alfieri, A., Alfieri, A. (2005), Bovine herpesvirus type 1 abortions detected by a semi-nested PCR in Brazilian cattle herds. Res Vet Sci, 79, 85-88
Wood, R. (1992), Enzootic abortion costs home industry $£ 20 \mathrm{~m}$ pa. Farmer Weekly, 117, 60

Wosiacki, S. R., Barreiro, M. A., Alfieri, A. F., Alfieri, A. A. (2005), Semi-nested PCR for detection and typing of bovine papillomavirus type 2 in urinary bladder and whole blood from cattle with enzootic haematuria. J Virol Methods, 126, 215-219 